\title{
Gestão social: reflexões teóricas e conceituais
}

\author{
Social management: theoretical and conceptual reflections
}

\author{
Airton Cardoso Cançado ${ }^{1}$ \\ Fernando Guilherme Tenório ${ }^{2}$ \\ José Roberto Pereira ${ }^{3}$
}

\section{Resumo}

O objetivo deste artigo é apresentar os avanços e discutir as críticas em relação à gestão social, além de apresentar contribuições para possível delimitação inicial desse campo de conhecimento, que se entende aqui, está em construção. Foi realizada uma revisão de literatura acerca dos aportes teóricos sobre o tema. São apresentadas e discutidas as principais críticas e elencadas as contribuições para a delimitação do campo. $O$ artigo também aborda a importância do tema e a reconstrução da origem do termo gestão social. Na percepção dos autores deste texto, a gestão social é antitética à gestão estratégica uma vez que a sua preocupação é com o envolvimento de todos no processo de tomada de decisão coletiva; contrária, portanto, à gestão estratégica cujo arcabouço conceitual e instrumental está vinculado a mecanismos decisórios baseados na hierarquia. Em síntese, a gestão social é apresentada como a tomada de decisão coletiva, sem coerção, baseada na inteligibilidade da linguagem, na dialogicidade e no entendimento esclarecido como processo, na transparência como pressuposto e na emancipação enquanto fim último.

Palavras-chave: Gestão social. Gestão estratégica. Emancipação.

\section{Abstract}

The aim of this paper is to present the advances and discuss the critiques of social management, besides presenting possible contributions to the initial delineation of this field of knowledge, what is here understood as being under construction. A review of the literature regarding theoretical contributions to the subject was conducted. The main critiques are presented and discussed and the contributions for the delimitation of the field are listes. The article also

Artigo submetido em 15 de março de 2011 e aceito para publicação em 04 de agosto de 2011.

1 Doutorando em Administração pela Universidade Federal de Lavras (UFLA); Mestre em Administração pela Universidade Federal da Bahia (UFBA); Professor Assistente III na Universidade Federal do Tocantins (UFT); Coordenador do Núcleo de Economia Solidária da UFT. Endereço: Campus da UFT Palmas, Quadra 109 Norte, NS15, s/n, Bloco II, Sala19 - Caixa Postal 114, Plano Diretor Norte, Palmas - TO, Brasil, CEP 77001-090. E-mail: airtoncardoso@yahoo.com.br

2

Pós-Doutorado em Administração Pública pelo IGOP/Universitat Autónoma de Barcelona - UAB; Doutor em Engenharia da Produção pela COPPE/Universidade Federal do Rio de Janeiro; Professor Titular da Escola Brasileira de Administração Pública e de Empresas (EBAPE) da Fundação Getulio Vargas (FGV); Coordenador do Programa de Estudos em Gestão Social (PEGS); Bolsista de Produtividade em Pesquisa 2 (Cnpq); Endereço: Praia de Botafogo, 190, Botafogo, CEP 22250-145, Rio de Janeiro - RJ, Brasil. E-mail: fernando.tenorio@fgv.br

3 Doutor em Sociologia pela Universidade de Brasília (UnB); Professor Associado da Universidade Federal de Lavras (UFLA); Bolsista CNPq e Pesquisador Mineiro pela FAPEMIG. Endereço: Universidade Federal de Lavras (UFLA), Diretoria de Contratos e Convênios - DICON - Prédio da Reitoria, Térreo, CEP 37200-000, Lavras - MG, Brasil. E-mail: ipereira@ufla.br 
discusses the importance of the theme and the reconstruction of the origin of the term social management. In the perception of the authors, social management is antithetical to strategic management since its concern is with the involvement of everyone in the process of collective decision-making; this is thus in contrast with strategic management, where the conceptual framework and instruments are linked to decision-making mechanisms based on the hierarchy. In short, social management is presented as collective decision-making, without coercion, based on the intelligibility of language, dialogue and enlightened understanding as a process, transparency as a precondition and emancipation as the ultimate goal.

Keywords: Social management. Strategic management. Emancipation.

\section{Introdução}

Nunca foi tão latente na academia a busca por alternativas teóricas no campo da Administração. O esgotamento das teorias organizacionais tradicionais, que desde a década de 1980 vem sendo anunciado por Guerreiro Ramos, Tragtenberg, Prestes Motta, dentre outros, nos mostra que a literatura anglo-saxônica na área pouco tem feito além de reeditar em novas embalagens os mesmos preceitos do taylorismo-fordismo.

No Brasil, especialmente nos cursos de Administração, vamos absorvendo e retransmitindo este conhecimento monológico anglo-saxônico em disciplinas como Teoria Geral da Administração com seus Best Sellers. Os alunos dos primeiros períodos na graduação "absorvem" este conhecimento e podem passar a acreditar que a Administração é praticamente uma ciência exata: diagnóstico-prescrição-solução.

Somado a isso, as palestras motivacionais com pretensos conteúdos práticos (como se a teoria pudesse estar separada da prática) são apresentadas a esses mesmos alunos como se fosse o último Bestway taylorista "descoberto" na área. Complementando esse cenário, a dita "literatura de aeroporto" enumera as melhores práticas para gestão, ou mesmo para "fazer amigos e influenciar pessoas".

Neste contexto não fica difícil perceber porque o tema gestão social tem atraído tanta atenção. Apesar de os céticos do mainstream torcerem o nariz, acreditando que a gestão tradicional seria um "Leito de Procusto", existe um movimento de pesquisadores no país que desde a década de 1990 vem se debruçando sobre esta temática e, principalmente, a partir da segunda metade da primeira década deste século, com a criação de programas de pesquisa, encontros especializados e mesmo periódicos dedicados ao tema.

Considerando esse contexto, vamos apresentar neste artigo os avanços e as críticas em relação à gestão social, e propor uma delimitação inicial para este campo em construção. Para tanto, foi realizada uma revisão de literatura acerca dos aportes teóricos sobre o tema. São apresentadas e discutidas as principais críticas e, em seguida, elencadas as contribuições para a delimitação do campo.

O artigo está dividido em seis partes, iniciando com esta introdução, seguida da reconstrução da origem da gestão social. Na seção seguinte são apresentados os aportes teóricos para a gestão social, e na quarta seção apresentam-se as críticas e sua discussão. Na sequência apresentam-se as contribuições para uma proposta de delimitação para a gestão social e as considerações finais.

\footnotetext{
4 Segundo Bianchetti (1995, p. 7-8), na mitologia grega Procusto capturava viajantes e os estendia em seu leito de ferro que servia como medida. Quem fosse menor que o leito era espichado, e quem fosse maior era amputado, o importante era manter a medida prévia, o padrão.
} 


\section{Gestão social: contexto bibliográfico}

Não foram encontradas na bibliografia pesquisada as origens da terminologia gestão social. A principal pista vem dos textos de Tenório, que desde 1990 está à frente do Programa de Estudos em Gestão Social (PEGS), vinculado à Escola Brasileira de Administração Pública e de Empresas (EBAPE) da Fundação Getúlio Vargas (FGV).

O primeiro contato de Tenório com o termo foi em um texto de Giorgio Rovida (1985) que trata de experiências autogestionárias na guerra civil espanhola (TENÓRIO, 2011). No referido texto, gestão social aparece com o significado de democracia proletária de caráter local (ROVIDA, 1985). Porém, o termo também é usado para descrever a gestão do $\operatorname{Sovkhoz}^{5}$ (fazendas coletivas na União Soviética comunista) (DICIONÁRIO..., 2011).

Tenório (2010) relata que em 1992, ao participar do Seminário Iberoamericano de Desarrollo de Profesores en Gerencia Social (Santa Cruz de La Sierra, Bolívia), o conceito foi tratado como referente a questões relativas a políticas públicas e ao terceiro setor, porém, neste evento foram despertadas outras expectativas, fruto dos debates no evento. Em seguida é lançado o livro Pobreza: un tema impostergable - Nuevas respuestas a nivel mundial compilado por Bernardo Kliksberg (KLIKSBERG, 1994a), provavelmente, o primeiro texto latino-americano que trata do tema gestão social (TENÓRIO, 2010). Neste texto, a gestão social é entendida como gestão de políticas públicas sociais (KLIKSBERG, 1994b). Assim, o "[...] o termo gestão social tem sido confundido quase exclusivamente com gestão de políticas e/ou programas sociais" (TENÓRIO e SARAIVA, 2006, p. 124) Esta confusão começou nos anos 1990 no Centro Latino-Americano de Administração para o Desenvolvimento - CLAD, e continuou no Instituto de Desenvolvimento Social do Banco Interamericano de Desenvolvimento (TENÓRIO e SARAIVA, 2006).

Em 1997, ao participar do curso Curso de Directivos em Diseño y Gestión de Políticas y Programas Sociales, promovido pelo Instituto Interamericano para o Desenvolvimento Social (INDES) do Banco Interamericano de Desenvolvimento (BID), em Washington D.C., nos Estados Unidos, o pesquisador ampliou sua percepção acerca da gestão social, e em 1998 publicou na Revista de Administração Pública (RAP) o artigo "Gestão social: uma perspectiva conceitual", possivelmente o primeiro texto nacional que tratava do assunto. Porém, o termo, ainda hoje,

[...] tem sido objeto de estudo e prática muito mais associado à gestão de políticas sociais, de organizações do terceiro setor, do combate à pobreza e até ambiental, do que à discussão e possibilidade de uma gestão democrática, participativa, quer na formulação de políticas públicas, quer naquelas relações de caráter produtivo. No PEGS $^{7}$, entretanto, o conceito de gestão social é entendido como o processo gerencial dialógico onde a autoridade decisória é compartilhada entre os participantes da ação. $\mathrm{O}$ adjetivo social qualificando o substantivo

5 "Sovkhoz - Fazenda soviética: grande empresa estatal agrícola da URSS, baseada na propriedade estatal da terra e dos meios de produção. Os sovkhozes começaram a ser organizados a partir de 1918, e desempenharam um grande papel na transformação socialista da agricultura, servindo de escola de gestão social e da produção agrícola para o campesinato. Em 1977 havia 20.100 sovkhozes e sua participação na produção total de produtos agropastoris era a seguinte: cereais= $44 \%$; algodão em rama=29\%; batatas $=18 \%$; hortaliças $=44 \%$; carne $=36 \%$; leite $=32 \%$; ovos $=57 \%$ e lã $=47 \%$. Para fortalecer a economia dos sovkhozes, foi realizado um trabalho baseado na intensificação, especialização e concentração da produção agropecuária e no desenvolvimento da cooperação e integração entre as empresas agroindustriais. Em outros países socialistas foram criadas, por analogia como os sovkhozes, empresas públicas baseadas na propriedade estatal dos meios de produção" (DICIONÀRIO..., 2011).

${ }^{6}$ O artigo é um dos capítulos de Tenório (2008b).

7 Programa de Estudos em Gestão Social da Escola Brasileira de Administração Pública e de Empresas da Fundação Getúlio Vargas do Rio de Janeiro - PEGS/EBAPE/FGV. 
gestão é percebido como o espaço privilegiado de relações sociais onde todos têm o direito à fala, sem nenhum tipo de coação (Tenório, 2008c, p. 147-148).

Esta percepção, embora ainda presente nos textos sobre gestão social, uma vez que o campo ainda está em construção, já apresenta indícios de que não consiga dar conta do que o próprio termo tem de potencial teórico e analítico.

Segundo Gomes et al. (2008, p. 59), “[...] pensar em gestão social, é pensar além da gestão de políticas públicas, mas sim estabelecer as articulações entre ações de intervenção e de transformação do campo social, que é uma noção mais ampla, e que não se restringe à esfera público-governamental, como vemos a exemplos das ações de responsabilidade social e do crescimento do terceiro setor".

Para Botrel, Araújo e Pereira (2010), a gestão social se desenvolve no âmbito da esfera pública, na qual se sobressaem as organizações públicas não-estatais e o interesse público da sociedade, além de proporcionar condições à emancipação dos indivíduos, baseando-se na democracia deliberativa, na formação da consciência crítica de seres humanos dotados de razão.

No Brasil, o termo gestão social encontra-se ainda em fase de construção (FISCHER e MELO, 2003, 2006; GIANELLA, 2008; BOULLOSA, 2009; BOULLOSA et al., 2009; BOULLOSA e SCHOMMER, 2008, 2009; DREHER, ULLRICH e TOMIO, 2010; JUNQUEIRA et al., 2009; MATOS et al., 2009; PINHO, 2010; RAMOS et al., 2009; SILVA JR. et al., 2008c), ou seja, a gestão social tem um caráter in progress (BOULLOSA, 2009). Por outro lado, a gestão social tem se consolidado enquanto prática, sem ainda o consenso sobre o conceito (PINHO, 2010). França Filho (2008, p. 26) adverte que a gestão social "[...] parece constituir nos últimos anos um daqueles termos que tem conquistado uma visibilidade cada vez maior, tanto do ponto de vista acadêmico, quanto, sobretudo, em termos mediáticos". Esta situação traz alguns problemas segundo o autor, um deles seria sua banalização, pois "tudo que não é gestão tradicional passa então a ser visto como gestão social" (FRANÇA FILHO, 2008, p. 26). Nesta perspectiva, Tenório (2008a, p. 158) aponta que a gestão social tem sido mais associada à gestão de políticas sociais ou até ambientais, "[...] do que à discussão e possibilidade de uma gestão democrática, participativa, quer na formulação de políticas públicas, quer nas relações de caráter produtivo".

Na revisão de literatura para este artigo foi possível identificar esta tendência à banalização. Nos textos pesquisados a gestão social é entendida de diversas formas: como gestão democrática ou participativa de políticas públicas sociais (RIZOTTI e NISHIMURA, 2006), gestão democrática do terceiro setor ou de ONGs (CARMO, SILVA e FONSECA, 2009), gestão ambiental (SASAKI e SOUZA, 2006), gestão democrática do desenvolvimento territorial (DELLABRIDA, 2006; COSTA, 2009), responsabilidade socioambiental (WANDERLEY et al., 2006). Ou ainda, o termo só aparece no título, como em Sasaki e Souza (2006). Esta situação confirma os argumentos de Silva Jr et al. (2008c) de que a gestão social tem sido alvo de diversas interpretações. Assim, tudo o que não é gestão tradicional (ou estratégica como prefere Tenório) passa a ser visto como gestão social (FRANÇA FILHO, 2008).

Atualmente, as principais referências conceituais sobre gestão social são os trabalhos de Tenório (2008a, 2008b, 2010, 2011), França Filho (2003, 2008), Fischer (2002), Fischer e Melo (2003, 2006), Boullosa (2009) e Boullosa e Schommer (2008, 2009). Em relação às críticas, o trabalho de Pinho (2010) questiona as possibilidades da gestão social, enquanto Boullosa (2009) e Boullosa e Schommer $(2008,2009)$ fazem um alerta em relação à transformação da gestão social de processo de inovação a produto inovador.

Anterior a este texto foram realizadas duas sistematizações sobre a produção em gestão social. O trabalho de Maia (2005) da área de serviço social tem como base principal o livro organizado por Rico e Raichellis (1999); o de Pimentel et al. (2011) é oriundo da área de Administração e apresenta um espectro maior de análise por ser mais recente. No Quadro 1 temos uma aproximação entre as duas análises e uma aproximação entre as categorias apresentadas pelos autores. 
Quadro 1

Categorias teóricas para a gestão social baseadas nos trabalhos de Maia (2005) e Pimentel et al. (2011)

\begin{tabular}{|c|c|c|c|}
\hline \multicolumn{2}{|c|}{ Maia (2005) } & \multicolumn{2}{|c|}{ Pimentel et al. (2011) } \\
\hline Categorias & Descrição & Descrição & Categorias \\
\hline Propósitos & $\begin{array}{l}\text { Viabilizar o } \\
\text { desenvolvimento da } \\
\text { sociedade. }\end{array}$ & $\begin{array}{l}\text { Interesse coletivo de caráter } \\
\text { público. }\end{array}$ & Objetivo \\
\hline Valores & Democracia e cidadania & $\begin{array}{l}\text { Interesse público bem } \\
\text { compreendido }\end{array}$ & Valor \\
\hline Agentes & $\begin{array}{l}\text { Atores em diversas } \\
\text { instâncias do Estado, } \\
\text { mercado e sociedade } \\
\text { civil. }\end{array}$ & $\begin{array}{l}\text { Sociedade civil organizada } \\
\text { (principal) em conjunto com } \\
\text { Estado e mercado. }\end{array}$ & Protagonista \\
\hline Metodologia & Processo social & $\begin{array}{l}\text { Social, parcerias e redes } \\
\text { intersetoriais. }\end{array}$ & Operacionalização \\
\hline Locos & $\begin{array}{l}\text { Organizações (Estado, } \\
\text { mercado e sociedade } \\
\text { civil), políticas públicas, } \\
\text { redes, interorganizações } \\
\text { e espaço local. }\end{array}$ & $\begin{array}{l}\text { Pública Social (França Filho) x } \\
\text { qualquer esfera (Tenório; } \\
\text { Dowbor). }\end{array}$ & Esfera \\
\hline \multirow[t]{4}{*}{ Focos } & \multirow{4}{*}{$\begin{array}{l}\text { Processo de afirmação } \\
\text { ou transformação do } \\
\text { desenvolvimento com } \\
\text { novos referenciais. }\end{array}$} & Substantiva/comunicativa & Racionalidade \\
\hline & & $\begin{array}{l}\text { Dialógica, com pouca ou } \\
\text { nenhuma restrição ao direito de } \\
\text { fala. }\end{array}$ & Comunicativa \\
\hline & & $\begin{array}{l}\text { Descentralizado, emergente e } \\
\text { participativo/surge como } \\
\text { construção coletiva. }\end{array}$ & Processo decisório \\
\hline & & $\begin{array}{l}\text { Não há coerção, todos têm } \\
\text { iguais condições de } \\
\text { participação (Tenório) x as } \\
\text { relações de poder restringem a } \\
\text { capacidade de cada um se } \\
\text { posicionar no debate (Fischer et } \\
\text { al.; Gondim, Fischer e Melo). }\end{array}$ & Autonomia e poder \\
\hline
\end{tabular}

Fonte: adaptado de Maia (2005) e Pimentel et al. (2011). 
Por meio do Quadro 1 pode-se notar uma grande aproximação entre as duas categorizações do significado de gestão social, com pequenas diferenças. O referencial teórico utilizado pelos trabalhos também é próximo, porém, em Maia (2005) não há referência a França Filho (2008), enquanto que em Pimentel et al. (2010) não há referência a Paul Singer (1999), além de serem considerados trabalhos mais recentes de Tânia Fischer.

Neste contexto de construção do campo da gestão social, começam a surgir centros de pesquisa e eventos que se dedicam ao estudo da temática. Silva Jr (2008a) apresenta a criação do PEGS/EBAPE/FGV, em 1990, como centro pioneiro no estudo da gestão social no Brasil. Em seguida, o estudo da gestão social se expande para algumas das principais Escolas de Administração do país, com destaque para o Centro Interdisciplinar de Desenvolvimento e Gestão Social da Universidade Federal da Bahia (CIAGS/UFBA), o Centro de Empreendedorismo Social e Administração em Terceiro Setor da Universidade de São Paulo (CEATS/USP), o Núcleo de Estudos de Administração do Terceiro Setor da Pontifícia Universidade Católica de São Paulo (NEATS/PUC-SP) e o Núcleo Interdisciplinar de Pesquisas e Estudos Sobre o Terceiro Setor da Universidade Federal do Rio Grande do Sul (NIPETS/UFRGS). Em um terceiro momento, o estudo da gestão social realiza o movimento de interioriorização, em alguns casos por meio de egressos dos programas citados. Destacam-se o Laboratório Interdisciplinar de Estudos em Gestão Social da Universidade Federal do Ceará - Campus Cariri - LIEGS/UFC-Cariri ${ }^{8}$, o Núcleo de Estudos em Administração Pública e Gestão Social (NEAPEGS) da Universidade Federal de Lavras, o Núcleo Interdisciplinar de Estudos e Tecnologias em Gestão Social da Universidade Federal do Vale do São Francisco - NIGS/UNIVASF e o Núcleo de Economia Solidária da Universidade Federal do Tocantins - NESol/UFT. Existem outros grupos se articulando pelo país, como na Universidade Federal de Viçosa (UFV) e Pontifícia Universidade Católica de Minas Gerais (PUC-Minas), ambas em Minas Gerais. Esta expansão dos centros acontece em um momento ainda de construção do campo, o que contribui para essa discussão ampliando o debate por um lado e, por outro, potencializando o entendimento esclarecido do termo e do próprio campo.

Estes pesquisadores se estabeleceram informalmente em uma rede, a Rede de Pesquisadores em Gestão Social (RGS) ${ }^{9}$, e o resultado mais visível de sua atuação foi a criação do Encontro Nacional de Pesquisadores em Gestão Social (ENAPEGS), em 2007, cujo idealizador foi o Prof. Jeová Torres Silva Jr. A primeira edição ficou a cargo do LIEGS/UFC-Cariri (Juazeiro do Norte/CE) (CARRION e CALOU, 2008; SILVA JR, 2008), (;) a segunda aconteceu em Palmas no ano seguinte, coordenada pelo NESol/UFT (CANÇADO et al., 2008a), (;) a terceira em Juazeiro/BA e Petrolina/PE, organizada pelo NIGS/UNIVASF (RIGO et al., 2010). Em 2010 o evento aconteceu em Lavras/MG, organizado pela Incubadora Tecnológica de Cooperativas Populares (INCUBACOOP-UFLA) e pelo NEAPEGS. As publicações oriundas destes eventos (CANÇADO et al., 2008a; RIGO et al.,2010; SILVA JR et al., 2008a) já são referências para o estudo da gestão social no país. Em 2011 o ENAPEGS foi realizado em Florianópolis, organizado pela Universidade do Estado de Santa Catarina (UDESC) / Centro de Ciências da Administração e Sócio-Econômicas (ESAG). Em 2012 o evento será sediado pela Pontifícia Universidade Católica de São Paulo.

Segundo Carrion e Calou (2008), a gestão social, apesar de ser um dos mais relevantes temas abordados nos últimos anos, sofre com a falta de espaço em periódicos de Administração, e as edições dos ENAPEGS são respostas a essa demanda dos pesquisadores na área.

Outro evento onde há o espaço para a discussão da gestão social é o Colóquio Internacional sobre Poder Local realizado pela UFBA, porém, o evento é trianual. Em Minas Gerais, por iniciativa do Prof. José Roberto Pereira, em 2009, foi realizado o I Encontro Mineiro de Administração Pública, Economia Solidária e Gestão Social (EMAPEGS) na Universidade Federal de Lavras, que teve sequência em junho de 2010 na Universidade Federal de Viçosa. O II EMAPEGS, seguindo a linha do ENAPEGS, também deu origem a

\footnotetext{
8 Um dos objetivos do LIEGS/UFC-Cariri é "[...] edificar um conceito mais preciso à gestão social” (SILVA Jr, 2008a, p. 168).

${ }^{9}$ Mais informações no site: www.rgs.wiki.br.
} 
uma publicação: Ferreira, Emmendoerfer e Gava (2011). O III EMAPEGS está previsto para se realizar em Lavras, em 2012.

A Associação Nacional dos Programas de Pós-graduação em Administração (ANPAD), em seus encontros anuais chegou a criar em 2003 a área Gestão Social e Ambiental, que em 2005 passou a ser uma subárea da área Administração Pública e Gestão Social, permanecendo assim até 2008. Em 2009, com a reestruturação das áreas temáticas, a área Administração Pública e Gestão Social foi dividida em 12 temas e nenhum deles contemplou a Gestão Social, que permaneceu apenas como título da área. Esta situação foi resolvida em 2010 com a exclusão de Gestão Social do título e a área passou a ser identificada, somente, como Administração Pública ${ }^{10}$. O Prof. Luis Felipe Nascimento encabeçou um grupo de pesquisadores que enviou, em setembro de 2009, à diretoria da ANPAD uma lista de 279 apoiadores da criação da área de "Sustentabilidade, Gestão Social e Ambiental", pois a área de Gestão Ambiental também teve o mesmo destino da Gestão Social. A diretoria da ANPAD rejeitou a proposta, pois não considerou a Gestão Social (e também a Gestão Ambiental) como uma área do conhecimento, e sim como uma área de aplicação como gestão hospitalar e gestão do agronegócio. Cabe ressaltar que a proposta não foi levada para a Assembleia da ANPAD, a decisão foi só da diretoria (NASCIMENTO, 2010).

O objetivo geral deste trabalho é discutir justamente o contrário da visão da diretoria da ANPAD. Não cabe aqui debater a validade ou não destas mudanças no mais importante evento acadêmico de Administração no país, porém, esta decisão se refletiu na importância do ENAPEGS, que passou de pouco mais de 170 trabalhos submetidos em 2009 para mais de 300 em 2010, o que demonstra que existe demanda de espaço para publicação da produção científica na área.

Partindo destas primeiras percepções, será realizada uma análise da gestão social no país em sua perspectiva conceitual.

\section{Gestão social: perspectivas de delimitação conceitual}

A abordagem de Tenório ${ }^{11}$ (2008a, 2008b) parte de uma inquietação relacionada ao status quo da Administração como área de conhecimento, despertada segundo o autor pela leitura da obra de Guerreiro Ramos, também usado como referência por também é citado por França Filho (2008) e Fischer (2002), dentre outros. Segundo Tenório, a gestão social poderia ser considerada como uma "linha de fuga" em relação à hegemonia da tradição positivista centrada na racionalidade utilitária do pensamento administrativo, que "[...] não tem permitido que os agentes do processo, administradores e administrados, desenvolvam suas ações de forma emancipadora" (TENÓRIO, 2008a, p. 31). O autor, baseado em Guerreiro Ramos e na Escola de Frankfurt (Horkheimer, Marcuse, Adorno) e, posteriormente, na "segunda geração" com Jürgen Habermas, constrói seu conceito de gestão social.

A construção do conceito acontece, inicialmente, pela análise dos pares de palavras ${ }^{12}$ Estado-sociedade e capital-trabalho, que são invertidas na sua ordem para sociedade-Estado e trabalho-capital, ressaltando a importância da sociedade e do trabalho como protagonistas destas relações. Ampliando a discussão, insere-se o par de palavras sociedade-mercado, que representa o processo de interação da sociedade civil organizada com o mercado, onde também a sociedade deve ser protagonista (TENÓRIO, 2008a, 2008b).

\footnotetext{
${ }^{10}$ Informações obtidas no site da instituição: www.anpad.org.br, acesso em 31 de março de 2010.

${ }^{11}$ Estes dois livros são coletâneas de artigos, publicados anteriormente pelo autor, a partir de 1990.

${ }^{12}$ Tenório assinala os pares de palavras no original em itálico, optou-se por manter este padrão também neste texto.
} 
Continuando seu caminho, o autor propõe que a cidadania deliberativa deve intermediar a relação entre estes pares de palavras, para o autor "[...] cidadania deliberativa significa, em linhas gerais, que a legitimidade das decisões deve ter origem em processos de discussão orientados pelos princípios da inclusão, do pluralismo, da igualdade participativa, da autonomia e do bem comum" (TENÓRIO, 2008a, p. 160, grifos do autor). A cidadania deliberativa "[...] faz jus à multiplicidade de formas de comunicação [...]" e "[...] une os cidadãos em torno de um auto-entendimento ético" (TENÓRIO, 2008b, p.167)

Sob esta perspectiva, a esfera pública seria o espaço de intermediação entre Estado, sociedade e mercado, bem como a cidadania deliberativa seria o processo participativo de deliberação baseado essencialmente no entendimento (e não no convencimento ou negociação) entre as partes (TENÓRIO, 2008a, 2008b) e “[...] o procedimento da prática da cidadania deliberativa na Esfera Pública é a participação" (TENÓRIO, 2008b, p. 171, grifos do autor).

Diferente de um processo centralizador, tecnoburocrático, elaborado em gabinetes, em que o conhecimento técnico é o principal argumento da decisão, sob uma perspectiva descentralizadora, de concepção dialógica, a esfera pública deve identificar, compreender, problematizar e propor as soluções dos problemas da sociedade, a ponto de serem assumidas como políticas públicas pelo contexto parlamentar e executadas pelo aparato administrativo de governo (TENÓRIO, 2008b, p. 162).

Segundo Subirats (2007b), a pesquisa de Tenório (2007) reivindica “[...] o espaço público como cenário no qual se propagam as potencialidades da democracia deliberativa com o protagonismo da cidadania" e, neste contexto, "o conceito de gestão social tem [...] um grande potencial transformador, que vai além da captura tecnocrática que do termo 'governance' as grandes organizações internacionais foram fazendo" (SUBIRATS, 2007b, p. 627).

Outra definição essencial para a construção do conceito de gestão social de Tenório é o agir comunicativo de Habermas. Para o autor a gestão social se baseia no entendimento, estreitamente vinculado com a linguagem, pois, "no processo de gestão social [...] a verdade é a promessa de consenso racional, [...] não é uma relação entre o indivíduo e a sua percepção de mundo, mas sim um acordo alcançado por meio da discussão crítica, da apreciação intersubjetiva" (TENÓRIO, 2008b, p. 27).

O contraponto entre gestão social e gestão estratégica ${ }^{13}$ baseia-se nos conceitos de racionalidade substantiva e racionalidade utilitária de Guerreiro Ramos, respectivamente. Para o autor, uma "possível saída" seria a racionalidade comunicativa de Habermas (TENÓRIO, 2008a). Nesse sentido, Tenório (2008b) mostra a hegemonia da racionalidade instrumental como empecilho para a emancipação do homem e de sua autonomia social, pois esta racionalidade já ultrapassa o ambiente de trabalho e invade todas as esferas da vida (GUERREIRO RAMOS, 1981). A gestão social seria o caminho para esta emancipação, pois incita a um "[...] gerenciamento mais participativo, dialógico, no qual o processo decisório é exercido por meio de diferentes sujeitos sociais" (TENÓRIO 2008b, p. 25-26). Na gestão social "[...] a hegemonia das ações possui caráter intersubjetivo. Isto é, onde os interessados na decisão, na ação de interesse público, são participantes do processo decisório" (TENÓRIO e SARAIVA, 2006, p. 128).

Assim, para Tenório (2008b, p. 158, grifos do autor) a gestão social é entendida "como processo gerencial dialógico em que a autoridade decisória é compartilhada entre os participantes da ação (ação que possa ocorrer em qualquer tipo de sistema social - público, privado ou de organizações não-governamentais). $\mathrm{O}$

\footnotetext{
${ }^{13}$ Segundo Feyerabend (2007) "[...] algumas das mais importantes propriedades formais de uma teoria são descobertas por contraste, e não por análise", pois as teorias devem ser comparadas antes com outras teorias "[...] do que com a 'experiência' e tem de tentar aperfeiçoar, em vez de descartar, as concepções que fracassaram nesta competição" (p.46).
} 
adjetivo social qualificando o substantivo gestão será entendido como o espaço privilegiado de relações sociais no qual todos têm o direito à fala, sem nenhum tipo de coação".

Segundo Tenório (2010), o processo de construção conceitual de gestão social se daria por meio de um processo dialético negativo, sem pretensão de síntese conceitual, pois o termo ainda precisa transcender o espectro da gestão estratégica. Este marco conceitual "tem a pretensão somente de enfatizar a necessidade de que os gestores, qualquer que seja a configuração jurídica da organização, atuar sob uma perspectiva na qual o determinante de suas ações deve ser a sociedade e não o mercado" (TENÓRIO, 2010).

Em seu texto mais recente, Tenório (2011) faz três suposições acerca da gestão social: 1) o conceito é subserviente à realidade não-republicana brasileira; 2) o conceito é uma utopia dada a sua pretensão antinômica ao de gestão estratégica; e 3) é um não-conceito, uma mediação entre a consciência e a realidade. Em relação à primeira suposição, o autor argumenta que o Brasil ainda não é uma sociedade republicana, ainda não possui uma cultura decisória voltada para o bem comum, por isso os interesses particulares se sobrepõem aos interesses coletivos, inviabilizando a gestão social. A segunda suposição aponta para a hegemonia da racionalidade utilitária/gestão estratégica como referência para se tornar a gestão social uma utopia, pois a mesma não cabe em pressupostos instrumentais. A gestão social deve ser baseada em "[...] um conteúdo de permanente promoção da cidadania [...]" (TENÓRIO, 2011) em todas as esferas de decisão, públicas e privadas. As pessoas que serão afetadas pelas decisões devem participar delas. Assim, "[...] a sociedade deve ser o determinante da análise, [...] o bem-comum é a referência, a responsabilidade social é o compromisso, a república é o norte" (TENÓRIO, 2011).

França Filho $(2003,2008)$ enfatiza a distinção entre gestão pública, gestão privada (ou gestão estratégica) e gestão social, por meio de uma comparação, aproximando e distanciando os conceitos para compreendê-los. Neste sentido, a gestão social é entendida pelo autor em duas perspectivas, como processo e como fim. Enquanto problemática de sociedade, ou seja, a gestão social enquanto fim (nível macro) se aproximaria da gestão pública, pois ambas buscam atender às demandas e necessidades da sociedade. Entende-se que a gestão das demandas da sociedade pode acontecer para além do Estado, via sociedade. Por outro lado, a gestão social enquanto processo, vista como uma modalidade específica de gestão (nível organizacional) busca "subordinar as lógicas instrumentais [típicas da gestão privada/estratégica] a outras lógicas, mais sociais, políticas, culturais ou ecológicas" (FRANÇA FILHO, 2008, p. 30).

[Gestão social] corresponde então ao modo de gestão próprio às organizações atuando num circuito que não é originariamente aquele do mercado e do Estado, muito embora estas organizações entretenham, em grande parte dos casos, relações com instituições privadas e públicas, através de variadas formas de parcerias para consecução de projetos. Este é o espaço próprio da chamada sociedade civil, portanto uma esfera pública de ação que não é estatal (FRANÇA FILHO, 2008, p. 32).

Tânia Fischer (2002, p. 29) apresenta a gestão social como "gestão do desenvolvimento social", definido pela autora como um espaço "[...] reflexivo das práticas e do conhecimento constituído por múltiplas disciplinas". A gestão social seria ainda uma "proposta pré-paradigmática" que vem recebendo a atenção de muitos centros de pesquisa no Brasil e no exterior (FISCHER, 2002; FISCHER e MELO, 2003, 2006). Assim, "A gestão social pode ser definida como aquela orientada para o social (enquanto finalidade) pelo social (enquanto processo), norteada pelos princípios da ética e da solidariedade" (FISCHER e MELO, 2006, p. 17).

Um conceito importante para entender a perspectiva de Fischer (2002) e a de Fischer e Melo (2003, 2006) sobre gestão social e a própria atividade do gestor social é o de interorganizações. Os conceitos-chave para se entender as interorganizações são: território, redes sociais, redes de redes (FISCHER e MELO, 2003, 2006). 
O processo de desenvolvimento é mobilizado por organizações que trabalham juntas ou por interorganizações cuja principal característica é a hibridização ou a complexidade. As interorganizações são constituídas por organizações diferenciadas, conectadas por propósitos comuns, isto é, integradas. A associação se faz pela complementaridade portanto pela busca do diferente que possa cooperar para se atingir um resultado (FISCHER, 2002, p. 19, grifo da autora).

As interorganizações se aproximam do conceito de redes, porém, a diferença está na hibridização e complexidade das relações, pois são organizações necessariamente diferentes e a associação se faz pela complementaridade.

Fischer (2002) faz cinco proposições acerca da caracterização do campo da gestão social e de seus paradoxos. A primeira está relacionada à articulação de múltiplos níveis de poder que traz em seu bojo uma "[...] carga potencial de conflito de interesses entre atores envolvidos e entre escalas de poder" (FISCHER, 2002, p. 27). A segunda apresenta a gestão do desenvolvimento social como um campo com práticas híbridas e contraditórias, pois "[...] A cooperação não exclui a competição; a competitividade pressupõe articulações, alianças e pactos." (FISCHER, 2002, p. 28) A terceira delineia o campo como marcado pela ética e pela responsabilidade que deve atender aos imperativos da eficácia e eficiência, porém, estes termos são tratados dentro da especificidade do campo, "[...] prestar contas à sociedade, avaliar processos e resultados e regular ações são também tarefas essenciais do gestor eficaz. No caso de organizações de desenvolvimento social, a eficiência é função de efetividade social, isto é, da legitimidade conquistada" (FISCHER, 2002, p. 28). A quarta proposição mostra que a gestão do desenvolvimento social é também a gestão de redes e de relações pessoais e sua subjetividade que são afetadas por muitos fatores, dentre eles a história do gestor. A quinta proposição mostra a importância do contexto cultural, pois "o gestor social é um gestor do simbólico e do valorativo, especialmente quando se trata de culturas locais e da construção de identidades" (FISCHER, 2002, p. 28).

Segundo Fischer (2007), a gestão social, dadas estas especificidades e nosso atual contexto seria a gestão do futuro. Matos et al. (2009) e Silva Jr. (2008) corroboram com esta proposição.

Segundo Boullosa e Schommer (2008, p. 9), "a característica da gestão social, na sua origem, era a inexistência de enfoques prescritivos". Enquanto processo, a gestão social implicava sempre uma atividade cognitiva e, portanto, a aprendizagem individual está ligada à aprendizagem coletiva (BOULLOSA e SCHOMMER, 2008, 2009). Outra característica da gestão social, nos seus primórdios é que "o foco não estava nas partes, mas na interação entre as partes, não na finalidade, sim na interação entre finalidades, definindo o caráter identitário meta-interacional das experiências" (BOULLOSA e SCHOMMER, 2009, p. 5, grifo das autoras).

As autoras apresentam quatro momentos evolutivos da gestão social. No primeiro, diferentes e dispersas experiências de gestão mostram a possibilidade de alcançar objetivos sociais por meio do diálogo e da participação das pessoas. No segundo, algumas experiências passam a ser reconhecidas e valorizadas por suas características inovadoras e seus participantes identificam pontos em comum, iniciando a articulação de práticas antes dispersas. No momento seguinte, elementos e léxicos comuns dessas experiências passam a ser percebidos como características identitárias de um modo de gerir problemas sendo elevadas à categoria de campo de gestão particular, que passa a ser denominado gestão social, ainda com forte presença de outras terminologias (gestão participativa, gestão socialmente responsável, etc.) surgindo projetos, cursos, eventos, metodologias e instrumentos de gestão e de formação em gestão social; a gestão social passa a ser uma opção de carreira. No último momento, a gestão social alcança certo grau de institucionalização e de modelização, porém, ainda não estão claras quais suas diferenças em relação aos outros tipos de gestão. Neste ponto, onde estamos atualmente, as autoras supõem que a gestão social abre mão de parte de seu potencial de inovação (BOULLOSA, 2009; BOULLOSA e SCHOMMER, 2008, 2009). 
As autoras alertam que a gestão social vem se transformando de processo de inovação a produto inovador e isto vem trazendo prejuízos à evolução do campo, que no entender das autoras se institucionalizou precocemente. Este alerta de Boullosa e Schommer $(2008,2009)$ será discutido na próxima seção.

As autoras consideram que o campo da gestão pública tem grande proximidade com o campo da gestão social $^{14}$ e que este pode constituir-se a partir das interações e limites da relação entre eles. Outra possibilidade é a utilização da abordagem social da aprendizagem (comunidades de prática) como possibilidade de se ensinar/aprender ${ }^{15}$ e exercer a gestão social (BOULLOSA, 2009; BOULLOSA e SCHOMMER, 2008, 2009). Esta perspectiva se aproxima da de Schommer e França Filho (2006, 2008, 2010). O campo da gestão social deve seguir estimulando e reconhecendo práticas diferenciadas e inovadoras bem-sucedidas, mesmo que em contextos específicos, para que possam ser embriões de ações de maior alcance, com potencial de gerar conhecimento inclusive para a gestão pública e gestão privada (BOULLOSA e SCHOMMER, 2008).

Serão apresentadas a seguir duas críticas em relação à gestão social, uma de caráter mais amplo, a de Pinho (2010), outra em relação à institucionalização precoce da gestão social, de Boullosa e Schommer (2008, 2009).

\section{Gestão social: críticas}

Em 2009, na mesa de abertura do III Encontro Nacional de Pesquisadores em Gestão Social - III ENAPEGS, na Cidade de Petrolina, foram convidados os professores José Antônio Gomes de Pinho (CIAGS/UFBA) e Fernando Guilherme Tenório (EBAPE/FGV). O Prof. Pinho proferiu uma palestra onde fez uma crítica contundente à construção do conceito de gestão social e às possibilidades da cidadania deliberativa. Esta palestra, a pedido da organização do evento, foi convertida em um artigo, Pinho (2010) e publicada no livro do evento em Rigo et al. (2010), seguida de uma réplica, publicada em Tenório (2010).

A primeira crítica de Pinho (2010) se refere ao próprio termo gestão social. Segundo o autor, o termo "gestão emancipadora" seria mais apropriado, pois "o termo social é muito convencional, indefinido e carregado de ambiguidades e pode ser aproveitado oportunisticamente" (PINHO, 2010, p. 25). Especificamente em relação à proposta de Tenório, discutida anteriormente, Pinho (2010) argumenta que "gestão solidária" seria o termo mais conveniente, pois, "o social é um termo muito fraco, indefinido, abrangente, ambíguo e anódino para conter a força e pretensão da proposta formulada por Tenório" (PINHO, 2010, p. 30).

Pinho (2010, p. 32) classifica a participação "[...] como seminal para apresentar a gestão social [...]". Neste sentido, esse autor argumenta que nosso contexto é diferente do europeu, onde o sucesso da participação está baseado em instituições sólidas e estáveis, nível de vida elevado com baixa disparidade econômica e ainda nas virtudes cívicas de solidariedade e de moderação, pois "a Alemanha de Habermas não é definitivamente aqui! Todas as condições requeridas pelo referencial habermasiano nos faltam, ainda que estejam em (lenta) construção" (PINHO, 2010, p. 33). Além disso, considera que a democracia direta tem diversas desvantagens, entre elas a incapacidade do povo para atuar no processo legislativo com as necessárias racionalidade e eficiência (PINHO, 2010).

\footnotetext{
${ }^{14}$ Esta foi a temática do IV ENAPEGS em 2010: "Gestão social e gestão pública: interfaces e delimitações". Mais informações: http://anaisenapegs2010.cariri.ufc.br/.

${ }^{15}$ Nota-se uma grande proximidade entre a concepção de comunidade de prática de Lave e Wenger (1991) com a abordagem de educação dialógica de Freire $(1987,1996,2001)$. Nas duas perspectivas o processo de aprendizagem é horizontal, onde a relação de autoridade é estranha ao processo e todos os participantes trazem suas experiências para o coletivo e ensinam aprendendo e aprendem ensinando.
} 
Outra frente de argumentação desse autor repousa na incapacidade da sociedade civil organizada de assumir o papel de "demiurgo do aprofundamento democrático", por não possuir qualificação técnica e política para participar da elaboração de políticas públicas. Além disso, o Estado tem um desenho autoritário e estranho à participação popular.

Em relação a experiências práticas, Pinho (2010) cita os problemas de funcionamento dos Conselhos Gestores: obrigatoriedade dos conselhos levando à participação por decreto, incapacidade dos conselheiros de representar suas instituições, desprestígio do Estado em relação a estas instâncias, dentre outras. O autor conclui que seria praticamente impossível que eles funcionem como se deseja nas atuais condições ou mesmo em situações ótimas. O autor reconhece, entretanto, que essas dificuldades são advindas de sua própria novidade, pois "[...] o Estado estaria aprendendo, ou tendo que aprender, a se abrir para a sociedade bem como esta teria que se instrumentalizar para forçar um diálogo efetivo com o Estado, o que representa, em ambos os casos, quebrar uma tradição historicamente constituída" (PINHO, 2010, p. 41).

Em síntese, uma das principais críticas aos Conselhos seria a tensão entre interesse individual/grupo e interesse coletivo/comunidade, que, segundo sua visão, seriam difíceis de separar e provavelmente incompatíveis. A implantação de um ambiente participativo e dialógico seria perigosa nestas condições, pois "há um risco elevado" da hegemonia da elite, que estaria mais preparada (PINHO, 2010, p. 46).

A crítica central de Pinho (2010) e a sua sugestão estão centradas na educação, pois considera que, para haver a tomada de decisão coletiva sem coerção, seria necessário que houvesse participação e a participação aconteceria apenas por meio da educação, o que não é uma realidade no Brasil ainda. Segundo o autor, "mais especificamente, entendemos a questão da educação como chave. Se existe alguma participação essencial, esta reside na participação, no saber, não desmerecendo o saber popular, mas consciente de que a entrada no mundo moderno e contemporâneo exige uma série de conhecimentos básicos e amplos, sem as quais o cidadão (ou candidato à) fica à margem" (PINHO, 2010, p. 44).

O autor cita ainda o exemplo de um estudo feito entre os afiliados à Associação de Professores Universitários da Bahia (APUB), do qual fez parte, relatando que na pesquisa

\begin{abstract}
constatou-se uma participação irrisória tanto no plano presencial como no digital. As questões levantadas só mobilizaram uma parcela ínfima dos potencialmente participáveis, sendo que esta participação só ocorria em cima de situações de interesse direto, instrumental dos envolvidos, chegando os pesquisadores à conclusão de que a participação não é um forte da sociedade brasileira, mesmo para grupos que têm todas as condições de participar de um debate deliberativo (PINHO, 2010, p. 43-44).
\end{abstract}

O que pode parecer à primeira vista um "balde de água fria" na discussão sobre gestão social, pode também ser interpretado como um incentivo a um aprimoramento teórico da discussão. A crítica de Pinho (2010) e outras que por ventura aconteçam são essenciais para preencher os "vazios teóricos e estruturais" de um campo em construção.

No que tange a nomenclatura gestão social, segundo o Moderno Dicionário da língua Portuguesa - Michaelis, social significa:

Social. adjm+f (latsociale) 1 Pertencente ou relativo à sociedade. 2 Que diz respeito a uma sociedade. 3 Sociável. 4 Próprio dos sócios de uma sociedade. 5 Conveniente à sociedade ou próprio dela. 6 Relativo, pertencente, devotado ou apropriado ao intercurso ou às relações amigáveis ou por elas caracterizado: Função social. 7 Relativo ou pertencente à sociedade humana considerada como entidade dividida em classes graduadas, segundo a posição na escala convencional: Posição social, condição social, classe social. 8 Relativo à vida do homem em sociedade: Ciências sociais. 9 Social Relativo ou pertencente às 
manifestações provenientes das relações entre os seres humanos, inclusive aquelas que constituem o campo específico da Sociologia: Problemas sociais. 10 Histnat Aplica-se a certos animais e plantas que vivem em grupos mais ou menos numerosos. (MICHAELIS, 2011, grifos do original).

Desta forma a gestão social coaduna com seu significado no dicionário, pois é uma gestão realizada pela sociedade (coletiva) e para a sociedade. A academia tem por costume e ofício sistematizar seu conhecimento e daí surgem os termos/expressões que muitas vezes não são tão precisos, o que não é o caso do termo gestão social. O que pode causar confusão é a própria banalização do termo e seu uso por quem não conhece o significado.

Os dicionários da área, talvez pela novidade da utilização do termo, ainda não definem gestão social ${ }^{16}$. O "Dicionário Internacional da Outra Economia" ${ }^{17, " ~(C A T T A N I ~ e t ~ a l ., ~ 2009) ~ t r a z ~ a p e n a s ~ a ~ d e f i n i c ̧ a ̃ o ~ d e ~}$ autogestão; o "Dicionário de Trabalho e Tecnologia" (CATTANI e HOLZMANN, 2006) apresenta apenas o termo gestão participativa (dos funcionários na gestão da empresa) e o "Dicionário Enciclopédico de Administração" traz o conceito de auto-administração ${ }^{18}$.

Em relação às (im)possibilidades e perigos da participação ampliada à população, a posição defendida aqui é que a participação pode e deve ser (re)construída no espaço público. Concordamos com Freire (1987, 1996, 2001) que a educação dialógica (respeito aos saberes e competências existentes) é um caminho longo e difícil, talvez improvável, mas possível, neste sentido. Desta forma, a proposta seria a construção da participação/cidadania durante o processo e não depois de uma educação ampla, como propõe Pinho (2010). O próprio processo de deliberação coletiva, com todos os seus erros e acertos, dificuldades e até utopias, é parte do processo de educação (LÜCHMANN, 2007). Se não fosse assim, poderíamos pensar na "ditadura do saber" que naturaliza estruturas burocráticas (MOTTA e BRESSER-PEREIRA, 2004) como a única forma de conceber a gestão. Além disso, o próprio controle social da ciência, defendido por Chalmers (1993, 1994), Feyerabend (2007) e Santos (2003), chama à responsabilidade da população o próprio direcionamento da ciência. Em uma perspectiva mais ampliada, Feyerabend (2007) critica a posição dos especialistas que decidem sobre o destino de seres humanos sem consultá-los, mostrando que o próprio desentendimento entre os especialistas e seu distanciamento da realidade não garantem que a sua decisão seja a melhor. Santos (2003) aponta ainda que as classes dominantes, que detêm o monopólio do conhecimento científico, não o usam para melhorar as condições de vida da sociedade como um todo. Assim, esta participação, mesmo que 'precária', é não só necessária, mas deve ser um direito de quem sofrerá as consequências da decisão. A proposta de Aplicação Edificante do Conhecimento de Santos (2003) é um bom exemplo de como o cientista pode ser um apoio às classes menos esclarecidas neste embate.

Ainda neste sentido, o exemplo da Associação dos Professores Universitários da Bahia (APUB) nos mostra que a educação formal não é garantia de participação, como foi constatado.

Desta forma, mesmo que o Brasil não seja a Alemanha, nem se deseja isto, acredita-se nas possibilidades da gestão social enquanto campo do conhecimento. Talvez, a mais importante contribuição de Pinho (2010) nesta crítica seja a de chamar a atenção às promessas que muitas vezes são feitas em nome da gestão social, sem as devidas ressalvas quanto às dificuldades que envolvem processos de participação. Os pés devem estar no chão, sim. Porém, uma boa parte dos pesquisadores em gestão social realiza ações concretas (de ensino, pesquisa e extensão) relacionadas à economia solidária, educação popular, organizações da sociedade civil,

\footnotetext{
${ }^{16}$ Existe um Dicionário da FUNDAP em elaboração, o verbete gestão social foi elaborado por Tenório.

${ }^{17}$ Esta "Outra Economia" é a Economia Solidária.

${ }^{18}$ Como o dicionário foi traduzido, o termo autoadministração (self-management) também poderia ter sido traduzido como autogestão.
} 
políticas públicas etc. Estes pesquisadores sentem na prática diária as dificuldades relacionadas a estes entraves apresentados por Pinho (2010), o que é muito importante para a construção do campo.

Os argumentos utilizados por Pinho (2010) são fortes e seguem uma linha de raciocínio coerente, o que valoriza sua crítica. ${ }^{19}$ Por outro lado, a crítica é coerente com a administração tradicional, tanto pública, quanto privada/estratégica e, apesar de citar brevemente, desconsidera várias experiências e instituições que têm mostrado que outras relações de consumo, poder, produção, convivência, etc. são possíveis. Alguns exemplos são o trabalho de Residência Solidária na UFRGS (CARRION, VALENTIM e HELLWIG, 2006), de gestão pública local em Jacobi e Pinho (2006), de Residência Social (FISCHER, ROESCH e MELO, 2006) e comunidades de prática (SCHOMMER e SANTOS, 2010) na UFBA, o trabalho realizado há quase duas décadas pela EBAPE/FGV (TENÓRIO, 2007a) e os recentes trabalhos do NESol/UFT (CANÇADO, PEREIRA e SILVA JR, 2007; CANÇADO, NASCIMENTO e GONÇALVES, 2008; CANÇADO et al., 2009).

Boullosa (2009) e Boullosa e Schommer (2008, 2009) apresentam a "precoce" institucionalização da gestão social como um problema a seu próprio desenvolvimento enquanto campo. A preocupação das autoras vem principalmente da criação de cursos de gestão social no país (na maioria das vezes profissionalizante, mesmo os mestrados) sem ainda haver uma referência concreta acerca do termo.

Segundo Boullosa e Schommer $(2008,2009)$ a passagem da gestão social de processo de inovação para produto inovador traz limitações para o tema, pois "[...] um processo implica sempre em uma atividade cognitiva coletiva, de aprendizagem, enquanto que um produto quase sempre implica em uma atividade cognitiva limitante, que tende ao isolamento, à definição de fronteiras" (BOULLOSA e SCHOMMER, 2008, p. 2). As autoras ainda argumentam que "[...] em processos de construção, todos se veem como aprendizes; quando o processo desemboca em produto, uns ensinam e outros aprendem, travando ou desacelerando um processo de desconstrução que estava em curso" (BOULLOSA e SCHOMMER, 2008, p. 2).

As autoras argumentam que, com a modelização, a gestão social assume um viés prescritivo, porém, os instrumentos ainda não estão consolidados, o que leva a um vazio, assim, "a gestão social se difundiu, muitos falam dela, tanto ensinam, muitos e muitos querem aprender e ninguém sabe precisamente do que se trata" (p.11). Este contexto tem gerado um desgaste que, segundo as autoras, é "[...] fortemente escondido pelas próprias comunidades que trabalham por sua institucionalização" (BOULLOSA e SCHOMMER, 2008, p. $11)$.

Por outro lado, a "incompletude" da gestão social seria sua grande riqueza, apesar de ser evidência de sua imaturidade (BOULLOSA, 2009). Porém, a autora reconhece que "a gestão social já conta com importantes avanços na construção de um arcabouço teórico-metodológico que a identifique melhor e promova a expansão de suas fronteiras" (BOULLOSA, 2009, p. 4).

Outro problema identificado pelas autoras, que parte do esforço da academia para delimitar o campo da gestão social, é a criação de hierarquias, antes inexistentes, que vêm da própria institucionalização acadêmica do campo. Segundo Boullosa e Schommer (2009, p. 8) "todo esse movimento vem instaurando certa hierarquia, antes inexistente, entre atores promotores da gestão social e seus estudiosos. Em decorrência, a gestão social passou a correr o risco de perder seu potencial de inovação, enquanto campo de experimentação e espaço de diversidade de práticas contra-hegemônicas, aproximando-se de campos e modos de gestão aos quais pretendia se opor, em sua gênese".

\footnotetext{
${ }^{19}$ Embora o mesmo seja Coordenador do CIAGS/UFBA.
} 
Para as autoras, esta situação “[...] começa a alterar o panorama da gestão social como campo de conhecimento, além de conferir a alguns o status de autoridade no assunto, no uso e na propagação de seus instrumentos" (BOULLOSA e SCHOMMER, 2009, p. 7).

Entende-se a preocupação das autoras em relação à rápida institucionalização do termo, talvez reflexo das próprias demandas sociais, tanto materiais quanto políticas. A população tem sentido mais necessidade de participar, a partir do momento que percebe que a democracia representativa não tem atendido a suas aspirações (LÜCHMANN, 2007).

Voltando ao alerta das autoras, faremos algumas considerações. Acreditamos que a evolução do campo da gestão social passa pela própria delimitação do campo, não vemos problema na institucionalização em si, mas em como a institucionalização acontece e para quê acontece. A construção de um campo com as características da gestão social não pode ter um viés prescritivo, sob pena de descaracterizar o próprio campo e esvaziá-lo de significado. Por outro lado, Boullosa e Barreto $(2009,2010)$ apresentam sinais positivos para a criação desses cursos.

Todavia, aquela mesma aceleração parece ter funcionado como terreno fértil para a inovação da relação entre ensino e aprendizagem em tais cursos, carentes, por dizer, de um passado, ainda que recente. De fato, até mesmo um olhar panorâmico sobre a oferta de formação em gestão social pode revelar a multiplicidade de interpretações não da temática em si, mas também diferentes explorações de componentes curriculares e estratégicas [sic] de ensino-aprendizagem que buscam relacionar teoria e/com prática, ensino e/com vivência, aprendizagem individual e /com aprendizagem social (BOULLOSA e BARRETO, 2010, p. 184).

Assim, entendemos de forma positiva a criação de cursos de gestão social, bem como a proliferação de encontros, projetos e periódicos sobre o tema como forma de discutir as possibilidades e desafios do próprio campo e de suas práticas. A única ressalva é o caráter dialógico que deve permear este processo. O caminho das comunidades de prática (LAVE e WENGER, 1991) é bastante promissor neste sentido (BOULLOSA, 2009; BOULLOSA e SCHOMMER, 2008, 2009; MEIRELLES e PEREIRA, 2010; SCHOMMER e FRANÇA FILHO, 2006, 2008, 2010). Se a gestão social se transformar em um conjunto de metodologias pré-fabricadas, como temem as autoras, com um arcabouço teórico monolítico, estaremos no caminho da prescrição. Porém, se a educação dialógica, nos moldes de Freire $(1987,1996,2001)$ e a construção de comunidades de prática for o caminho seguido, dificilmente a gestão social terá contornos prescritivos. A própria rede de pesquisadores em gestão social (RGS) e os encontros realizados pela rede têm aberto espaço em seus eventos, não sem dificuldades, para a sociedade civil organizada e o próprio poder público, no intuito de ampliar a discussão sobre o tema. Porém, acreditamos, e este trabalho é uma prova disto, que devemos, conceitualmente, delimitar a gestão social para que possamos pensá-la, repensá-la e estabelecer seus limites para mudá-los quando necessário. Uma das discussões mais avançadas em relação à filosofia da ciência é que não existe conhecimento certo, todo conhecimento é temporário e passível de ser substituído por um novo que explique melhor a realidade (CHALMERS, 1993; DEMO, 2007; FEYERABEND, 2007; KUHN, 1978; LAKATOS, 1999; POPPER, 2007; SANTOS, 2003).

A delimitação do campo da gestão social, principalmente se realizada de forma dialógica, não deve “engessar" o próprio desenvolvimento do campo, nem coibir novas práticas diferenciadas e inovadoras.

Em relação à hierarquização e ao estabelecimento de "autoridades" nas relações dentro do campo da gestão social, temos justamente a percepção contrária. Talvez seja a área da Administração onde mais exista abertura para entrada de novos participantes, haja vista a criação de novos centros de pesquisa em universidade menos tradicionais fora do sul e sudeste, a expansão do ENAPEGS e a própria relação entre os pesquisadores que compõem a rede. Os três primeiros ENAPEGS foram realizados por pesquisadores mestres, que provavelmente não seriam nem considerados pesquisadores em outros ambientes acadêmicos 
(no máximo aprendizes até a titulação de doutor). Além disso, desde 2010 o ENAPEGS estimula a participação de pesquisadores da graduação por meio da modalidade "Artigo de Iniciação Científica/Trabalho de Conclusão de Curso - Artigo IC/TCC", dando um tratamento diferenciado a estes trabalhos no intuito de formar novos pesquisadores. O apoio da Fundação CAPES, por meio do Edital PróAdministração ${ }^{\circ}$ 09/2008, é outra prova da importância que o tema gestão social tem tido na academia nos últimos anos. Entendemos que, com a institucionalização do campo, esta abertura possa ser cada vez mais restrita. Mais uma vez argumentamos que o que importa é como a institucionalização acontece, e como ela se renova.

Outra crítica apresentada pelas autoras é em relação ao fato da "precoce" institucionalização do campo exigir instrumentos de gestão que não existem, o que estaria sendo "[...] fortemente escondido pelas próprias comunidades que trabalham por sua institucionalização" (BOULLOSA e SCHOMMER, 2008, p. 11). Mais uma vez temos a percepção diferente da das autoras, assim como França Filho $(2003,2008)$ apresenta a falta destes instrumentos e a urgência em construí-los, a crítica de Pinho (2010) já apresentada também relata estes problemas. A avaliação do PEGS/EBAPE/FGV (TENÓRIO, 2006, 2008c), PDGS/UFBA (BOULLOSA e BARRETO, 2009, 2010; FISCHER et al., 2006, 2007, 2008; FISCHER e MELO, 2006; GONDIM, FISCHER e MELO, 2006a, 2006b) e do Programa de Residência Solidária da UFRGS (CARRION, 2008; CARRION, VALENTIM e HELLWIG, 2006) são outros exemplos, além dos próprios trabalhos das autoras (BOULLOSA, 2009; BOULLOSA; SCHOMMER, 2008, 2009). Outros trabalhos (CANÇADO e PEREIRA, 2011; CANÇADO, PROCÓPIO e PEREIRA, 2010; OLIVEIRA, CANÇADO e PEREIRA, 2010) também abordam os problemas da gestão social, bem como os de Pimentel et al. (2011) e Pimentel e Pimentel (2010).

A seguir serão apresentadas contribuições para a delimitação do campo do conhecimento em gestão social.

\section{Gestão social: contribuições para a delimitação do campo}

Pode-se notar, pelo exposto, que o campo da gestão social vem sendo delineado por diferentes autores nos últimos anos. O momento é oportuno, pois os alertas da provável vulgarização do campo, que no médio prazo poderiam ser irreversíveis, já foram dados (FRANÇA FILHO, 2003, 2008; OLIVEIRA, CANÇADO e PEREIRA, 2010).

A opção pela delimitação inicial do campo foi pensada em termos de características da gestão social, no sentido de delimitar o significado desse termo.

A característica que perpassa toda a discussão realizada até aqui é a tomada de decisão coletiva como uma das bases da gestão social. Tenório $(2008$ a, 2008b, 2010, 2011) propõe a cidadania deliberativa na esfera pública, França Filho (2008) fala da subordinação da lógica instrumental (baseada no poder hierarquizado) às outras lógicas, Fischer (2002) e Fischer e Melo (2003, 2006) apresentam a questão da articulação de múltiplos níveis de poder e das contradições entre interesses individuais e coletivos. Pinho (2010) tem na participação uma de suas principais críticas ao conceito de gestão social, por acreditar que ela seja difícil de ser alcançada.

Para que a decisão seja efetivamente coletiva, ela deve ser livre de coerção e todos devem ter a liberdade de manifestar o que pensam (TENÓRIO, 2008b). Além disso, a tomada de decisão é baseada no entendimento, na argumentação e não na negociação no sentido utilitário do termo. Estas características, justamente por estarem baseadas em Tenório (2008a, 2008b), aproximam-se da ação comunicativa habermasiana. Estas condições são interdependentes, pois, se a decisão é realmente coletiva, a coerção é estranha ao processo, e o entendimento (e não a negociação) deve ser seu caminho. Emerge aqui a dialogicidade como outra característica da gestão social. 
A transparência surge como condição necessária para as outras características, pois o segredo e a assimetria de informação tornam inviável a tomada de decisão coletiva baseada no entendimento esclarecido. Neste sentido, a linguagem deve ser inteligível a todos os participantes. Mais uma vez nos aproximamos da ação comunicativa de Jürgen Habermas no sentido da dialogicidade necessária à transparência pública.

Baseado em Freire (1987, 1996, 2001) e Tenório (2008a), temos a emancipação do homem como fim da gestão social, baseada nas características anteriores, no processo democrático deliberativo e no exercício pleno da cidadania. A participação efetiva no processo de tomada de decisão traz crescimento e amadurecimento para os atores (FREIRE, 1987, 1996, 2001), que ampliam sua visão de mundo enquanto seres humanos dotados de razão e cidadãos participantes de uma esfera pública.

As características discutidas acima podem ser consideradas como um tipo ideal weberiano, pois as relações de poder, desigualdades sociais e culturais podem facilmente nos levar a crer que estas características são impossíveis (ou pelo menos improváveis) de se verificar de forma plena na prática. Ser apresentada como tipo ideal não diminui a importância da construção teórica acerca da gestão social, pois pode-se argumentar que todos os tipos de gestão podem ser enquadrados como tipos ideais. O próprio processo de gestão social, por meio da sua potencialidade iminente de emancipação, tende a aumentar as possibilidades destas características se apresentarem. Em outras palavras, a gestão social enquanto prática, norteada por estas características, ao ampliar as possibilidades de emancipação, tende a reforçá-las. A participação periférica legítima que pode ser definida como um processo por meio do qual os aprendizes (ou novatos, ou ainda os que não conhecem determinado processo e suas regras) se tornam membros completos e obtêm legitimação através da participação na prática sócio-cultural da comunidade ou esfera pública é um constructo que reforça este argumento. O principiante vai construir sua participação legitimada pela ajuda de membros mais experientes do grupo, aprendendo por meio da observação da prática dos participantes com maior habilidade e conhecimento do processo e das regras do jogo. Porém, é importante constatar que a "participação periférica legítima" prevê mais do que a simples observação, envolvendo também a participação (cada vez mais qualificada, como um espiral em direção ao centro) como uma forma de aprendizado da cultura da prática (LAVE e WENGER, 1991).

Em síntese, a gestão social pode ser apresentada como a tomada de decisão coletiva, sem coerção, baseada na inteligibilidade da linguagem, na dialogicidade e no entendimento esclarecido como processo, na transparência como pressuposto e na emancipação enquanto fim último. Esta síntese não tem caráter prescritivo, em outras palavras, pode haver gestão social para além dela. O intuito aqui é a delimitação do campo não para "cercar o que tem dentro" e sim para criar fronteiras para serem mudadas com o decorrer das pesquisas e da própria prática na área.

\section{Considerações Finais}

Neste texto é apresentada uma contribuição que não esgota as possibilidades do campo, mas apresenta características para uma delimitação inicial do próprio significado da gestão social. Por ser uma contribuição inicial se fazem necessárias mais contribuições para esta empreitada.

Uma análise mais profunda dos aportes ao campo da gestão social pode dar algumas pistas do que pode ser importante para continuar no caminho da construção do campo. Schommer e França Filho (2006, 2008, 2010), Boullosa (2009), Boullosa e Schommer (2008, 2009) e Meirelles e Pereira (2010) apontam o conceito de comunidades de prática (LAVE e WENGER, 1991) como possibilidades para a formação do gestor social, indo um pouco além, as comunidades de prática podem vir a ser entendidas como um espaço por excelência da gestão social, pois sua lógica está ligada ao respeito e interação aos diferentes saberes (SCHOMMER e FRANÇA FILHO, 2006, 2008, 2010), próxima à educação dialógica proposta por Freire $(1987,1996,2001)$ em uma perspectiva que inclui a participação periférica legítima. Assim, um dos caminhos que se apresentam 
é a análise teórica das comunidades de prática como possibilidades de delimitação do campo da gestão social.

A perspectiva de Tenório (2008a, 2008b, 2010, 2011), baseada na cidadania deliberativa e na ação comunicativa de Habermas, também apresenta outra possibilidade bastante promissora para esta agenda de pesquisa, que já foi bem desenvolvida pelo autor e que pode ser um referencial importante nesta construção.

A comunicação dialógica de Paulo Freire (1987) é outro aporte que pode ser central nesta busca, pois o respeito ao interlocutor está presente nas características da gestão social. É importante considerar que o processo em si é dialógico.

Finalmente, aqui não se considerou a gestão social como a "salvação" quanto ao esgotamento conceitual da Administração como área de conhecimento, a gestão social é uma alternativa teórica e prática ao pensamento organizacional hegemônico. Na percepção dos autores deste texto, a gestão social é antitética a gestão estratégica, uma vez que a sua preocupação é com o envolvimento de todos os concernidos nos processo de tomada de decisão contrária, portanto, a gestão estratégica cujo arcabouço conceitual e instrumental não potencializa processos decisórios participativos, mas sim mecanismos decisórios hierarquizados acentuando, cada vez mais, a luta de classes no interior das organizações e destas com a sociedade. A visão social de mundo da gestão social tem como o seu determinante a sociedade, enquanto o enfoque adotado pela gestão estratégica é o mercado.

\section{Referências}

BIANCHETTI, L. Aspectos históricos da educação especial. Revista Brasileira de Educação Especial, 1995. Disponível em <http://scholar.google.com.br/scholar?q=leito+de+procusto\&hl=pt-BR\&lr=lang_pt>. Acesso em 31 out. 2010.

BOTREL, M. de O.; ARAÚJO, P. G. de; PEREIRA, J. R. Entre a Gestão Pública e a Gestão Social de Bens Culturais no Brasil. In Encontro Nacional de Pesquisadores em Gestão Social, 4, 2010, Lavras. Anais..., Lavras: INCUBACOOP, 2010. 1 CD ROM.

BOULLOSA, R. de F. Contribuições conceituais e metodológicas para a avaliação de processos e práticas de gestão social a partir das perspectivas da policyanalysis e da abordagem social da aprendizagem. In Colóquio Internacional sobre Poder Local, 11, 2009, Salvador. Anais..., Salvador: CIAGS/UFBA, 2009. 1 CD ROM.

.; ARAÚJO, E. T. de; FISCHER, T. M. D.; MELO, V. P.; BARRETO, Maria Leonesy da Silveira. Avaliação participativa de práticas de ensino que vinculam intervenção e pesquisa em programas de formação em gestão social. In Encontro Nacional de Pesquisadores em Gestão Social, 3, 2009, Juazeiro/Petrolina. Anais..., Juazeiro/Petrolina: NIGS/UNIVASF, 2009. 1 CD ROM. (Oficina)

.; BARRETO, M. L. da S. Revisando a experiência transdisciplinar da residência social na formação em gestão social e desenvolvimento através da perspectiva da aprendizagem situada e significativa. In Colóquio Internacional sobre Poder Local, 11, 2009, Salvador. Anais..., Salvador: CIAGS/UFBA, 2009. 1 CD ROM.

A Residência Social como experiência de aprendizagem situada e significativa em cursos de gestão social e gestão pública. NAU - Revista Eletrônica da Residência Social do CIAGS/UFBA, Salvador, v.1, n.1, p.181202, Jun/Nov, 2010.

, SCHOMMER, P. C. Limites da natureza da inovação ou qual o futuro da gestão social? In Encontro da Associação Nacional de Pós-Graduação e Pesquisa em Administração, 32, 2008, Rio de Janeiro. Anais..., Rio de Janeiro: ANPAD, 2008. 1 CD ROM. 
; _ _ Gestão social: caso de inovação em políticas públicas ou mais um enigma de lampedusa? In Encontro Nacional de Pesquisadores em Gestão Social, 3, 2009, Juazeiro/Petrolina. Anais..., Juazeiro/Petrolina: NIGS/UNIVASF, 2009. 1 CD ROM.

CANÇADO, A. C.; FINCO, M. V. A.; FINCO, F. D. B. A.; CANÇADO, A. C. M. G. Economia solidária e desenvolvimento sustentável: resultados da atuação do NESol/UFT no Bico do Papagaio/TO. Goiânia: Grafset, 2009.

.; NASCIMENTO, I. Q.; GONÇALVES, A. C. A. Economia solidária, autogestão e inclusão social: os desafios e resultados das ações do IES em Camaçari, no Estado da Bahia. Salvador: Provisão, 2008.

; PEREIRA, J. R. Pereira. Gestão Social: por onde anda o conceito? In FERREIRA, Marco Aurélio Marques; EMMENDOERFER, Magnus Luiz; GAVA, Rodrigo (Org.). Administração pública, gestão social e economia solidária: avanços e desafios. Viçosa: UFV, 2011, 350p.

.; ___ _ SILVA JUNIOR, J. T. Economia solidária, cooperativismo popular e autogestão: as experiências em Palmas/TO. Palmas: NESol/UFT, 2007.

.; PROCÓPIO, M. L.; PEREIRA, J. R. Marketing Social: Origens, Desenvolvimento e Perspectivas. In Encontro Nacional de Pesquisadores em Gestão Social, 4, 2010, Lavras. Anais..., Lavras: INCUBACOOP, 2010. 1 CD ROM.

.; SILVA JR, J. T.; SCHOMMER, P. C., RIGO, A. S. Os desafios da formação em gestão social. Palmas-TO: Provisão, 2008.

CARMO, E. D. do; SILVA, F.; FONSECA, S. O encontro das águas na(s) Amazônia(s): educação popular e gestão social pela via da experiência da UNIPOP. In Encontro Nacional de Pesquisadores em Gestão Social, 3, 2009, Juazeiro/Petrolina. Anais..., Juazeiro/Petrolina: NIGS/UNIVASF, 2009. 1 CD ROM.

CARRION, R. da S. M.; CALOU, Â. Pensar a gestão social em terras de ‘Padinho Cícero’ (Prefácio). In: SILVA JR, J. T.; MÂISH, R. T.; CANÇADO, A. C. Gestão Social: Práticas em debate, teorias em construção. Fortaleza: Imprensa Universitária, 2008.

; VALENTIM, I. V. L.; HELLWIG, B. C. (Org.). Residência solidária: vivências de universitários com o desenvolvimento de uma tecnologia social. Porto alegre: UFRGS, 2006, 208p.

CATTANI, A. D.; HOLZMANN, L. (Org.) Dicionário de trabalho e tecnologia. Porto Alegre: UFRGS, 2006, 358p.

; LAVILLE, J-L.; GAIGER, L. I.; HESPANHA, P.. Dicionário internacional da outra economia. Coimbra: Almedina, 2009, 346p.

CHALMERS, A. F. O que é ciência afinal? Tradução Raul Fiker. São Paulo: Brasiliense, 1993.

Básica)

A fabricação da ciência. Tradução de Beatriz Sidou. São Paulo: UNESP, 1994, 188p. (Coleção biblioteca

COSTA, P. de A. A abordagem territorial para a economia solidária: um desafio para os processos de gestão social do desenvolvimento. In Colóquio Internacional sobre Poder Local, 11, 2009, Salvador. Anais..., Salvador: CIAGS/UFBA, 2009. 1 CD ROM.

DALLABRIDA, V. R. A gestão social dos territórios nos processos de desenvolvimento territorial: uma aproximação conceitual. In Colóquio Internacional sobre Poder Local, 10, 2006, Salvador. Anais..., Salvador: CIAGS/UFBA, 2006. 1 CD ROM.

DEMO, P. Metodologia científica em ciências sociais. 3 ed. São Paulo: Atlas, 2007.

DICIONÁRIO POLÍtICO MARXISTS INTERNET ARCHIVE. Sovkhoz. Disponível em < http://www.marxists.org/portugues/dicionario/verbetes/s/sovkhoz.htm >. Acesso em 13 jan. 2011. 
DREHER, M. T.; UllRICH, D. R.; TOMIO, C. Gestão Social, Sustentabilidade e Terceiro Setor: Análise dos Programas Stricto Sensu em Administração. In Encontro Nacional de Pesquisadores em Gestão Social, 4, 2010, Lavras. Anais..., Lavras: INCUBACOOP, 2010. 1 CD ROM.

FERREIRA, M. A. M.; EMMENDOERFER, M. L.; GAVA, R. (Org.). Administração pública, gestão social e economia solidária: avanços e desafios. Viçosa: UFV, 2011, 350p.

FEYERABEND, P. K. Contra o método. Tradução: Cezar Augusto Morari. São Paulo: UNESP, 2007, 376 p.

FISCHER, T. M D. Poderes locais, desenvolvimento e gestão - uma introdução a uma agenda. In FISCHER, T. M D. (Org.). Gestão do desenvolvimento e poderes locais: marcos teóricos e avaliação. Salvador: Casa da Qualidade, p.12$32,2002$.

.; MELO, V. P. Gestão Social do Desenvolvimento e Interorganizações. In Colóquio Internacional sobre Poder Local, 9, 2003, Salvador. Anais..., Salvador: CIAGS/UFBA, 2003. 1 CD ROM.

.; _. Programa de desenvolvimento e gestão social: uma construção coletiva. In FISCHER, T. M D.; ROESCH, S.; MELO, V. P. Gestão do desenvolvimento territorial e residência social: casos para ensino. Salvador: EDUFBA, CIAGS/UFBA, p.13-41, 2006.

.; ___ SCHOMMER, P. C.; BOULlOSA, R. de F.; ARAÚJO, E. T. de. Avaliação de Programas de Pósgraduação em Gestão Social. In Encontro de Ensino e Pesquisa em Administração e Contabilidade - EnEPQ, 1, 2007, Recife. Anais..., Recife: ANPAD, 2007. 1 CD ROM.

Especial I ENEPQ, p 48-58, nov., 2008 Avaliação de Programas de Pós-graduação em Gestão Social. Gestão.Org, Número

.; MELO, V. P.; CARVALHO, M. R. de; JESUS, A. de; ANDRADE, R. A.; WAIANDT, C. Perfis visíveis na gestão social do desenvolvimento. Rev. Adm. Pública, v. 40, n. 5, p.789-808, Outubro, 2006.

.; ROESCH, S.; MELO, V. P. Gestão do desenvolvimento territorial e residência social: casos para ensino. Salvador: EDUFBA, CIAGS/UFBA, 2006.

FRANÇA FILHO, G. C. de. Gestão Social: um conceito em construção. In Colóquio Internacional sobre Poder Local, 9,2003, Salvador. Anais..., Salvador: CIAGS/UFBA, 2003. 1 CD ROM.

Definido Gestão Social. In: SILVA JR, J. T.; MÂISH, R. T.; CANÇADO, A. C. Gestão Social: Práticas em debate, teorias em construção. Fortaleza: Imprensa Universitária, 2008.

FREIRE, P. Pedagogia do oprimido. 17. ed. São Paulo: Paz e Terra, 1987, 186p.

Pedagogia da autonomia: saberes necessários à prática educativa. 29. ed. São Paulo: Paz e Terra, 1996.

Ação cultural para a liberdade e outros escritos. 9. ed. Rio de Janeiro: Paz e Terra, 2001.

GIANELLA, V. Base teórica e papel das metodologias não convencionais para a formação em gestão social. In CANÇADO, A. C.; SILVA JR, J. T.; SCHOMMER, P. C., RIGO, A. S. Os desafios da formação em gestão social. Palmas-TO: Provisão, 2008.

GOMES, G. da S.; OLIVEIRA, E. M. de; ANDREACI, C.; MORAES, N. R. de; ROZA, F. L. da; AMARAL, L. D. P. do; AMORIN, P. D. F.; MARTINELli, E. L.; BOWERCK, D. A.; MOREIRA, S. R. da S.; SANTANA, L. G.; TORRES, L. V. N. Residência Social \& EaD: alternativas multireferenciais nos estágios de graduação na UNITINS. In CANÇADO, A. C.; SILVA JR, J. T.; SCHOMMER, P. C., RIGO, A. S. Os desafios da formação em gestão social. Palmas-TO: Provisão, 2008b. 
GONDIM, S. M. G.; FISCHER, T.; MELO, V. P. Formação em Gestão Social: Um olhar crítico sobre uma experiência de pós-graduação. In Encontro da Associação Nacional de Pós-Graduação e Pesquisa em Administração, 30, 2006, Salvador. Anais..., Salvador: ANPAD, 2006a. 1 CD ROM.

;_________ Formação em gestão social: um olhar crítico sobre uma experiência de pós-graduação. In FISCHER, T. M. D.; ROESCH, S.; MELO, V. P. Gestão do desenvolvimento territorial e residência social: casos para ensino. Salvador: EDUFBA, CIAGS/UFBA, p.43-61, 2006b.

GUERREIRO RAMOS, A. A nova ciência das organizações: uma reconceituação da riqueza das nações. Tradução de Mary Cardoso. 2 ed. Rio de Janeiro: Editora da Fundação Getúlio Vargas, 1981, 210p.

JACOBI, P.; PINHO, J. A. G. de (Org). Inovação no campo da gestão pública local: novos desafios, novos patamares. Rio de Janeiro: FGV Editora, 2006.

JUNQUEIRA, L. A. P.; VINHAS, F. D.; PERRET, N.; TEIXEIRA, A. F. Parcerias e redes sociais: a busca pela gestão social eficaz - um estudo de caso. In Encontro Nacional de Pesquisadores em Gestão Social, 3, 2009, Juazeiro/Petrolina. Anais..., Juazeiro/Petrolina: NIGS/UNIVASF, 2009. 1 CD ROM.

KLIKSBERG, B. Pobreza: uma questão inadiável. Tradução de Cláudia Schiling. Brasília: ENAP, 1994a.

A gerência social, uma gerência diferente. In KLIKSBERG, B. Pobreza: uma questão inadiável. Tradução de Cláudia Schiling. Brasília: ENAP, 1994b.

KUHN, T. S. A estrutura das revoluções científicas. 2 Ed. São Paulo: Editora Perspectiva, 1978.

LAKATOS, I. Falsificação e metodologia dos programas de investigação científica. Tradução de Emília Picado Tavares Marinho Mendes. Edições 70, 1999, 208p. (Biblioteca de Filosofia Contemporânea 28).

LAVE, J.; WENGER, E. Situated learning: legitimate peripheral participation. Cambridge, UK: Cambridge University Press, 1991.

LÜCHMANN, L. H. H. A representação no interior das experiências de participação. Lua Nova, n.70, p. 139-170, 2007.

MAIA, M. Gestão social - reconhecendo e construindo referenciais. Revista Virtual Textos \& Contextos. N.4, Ano IV, dez. 2005

MATOS, I. M.; OLIVEIRA, L. G. L.; RAMOS, R. R.; COSTA, F. J. da. Importância percebida e intenções de envolvimento com a gestão social e ambiental: uma análise comparativa junto a estudantes de cursos de administração. In Colóquio Internacional sobre Poder Local, 11, 2009, Salvador. Anais..., Salvador: CIAGS/UFBA, 2009. 1 CD ROM.

MEIRELlES, D.; PEREIRA, J. R. Entraves Culturais De Aprendizagem Organizacional No Contexto Da Gestão Social. In Encontro Nacional de Pesquisadores em Gestão Social, 4, 2010, Lavras. Anais..., Lavras: INCUBACOOP, 2010. 1 CD ROM.

MICHAELIS - MODERNO DICIONÁRIO DA LÍNGUA PORTUGUESA. Social. Disponível em <http://michaelis.uol.com.br/moderno/portugues/index.php?lingua=portugues-portugues\&palavra=social>. Acesso em 01 mar. 2011.

MOTTA, F. C. P.; BRESSER-PEREIRA L. C. Introdução à organização burocrática. 2 ed. rev. São Paulo: Thomson Learning, 2004, 294p.

NASCIMENTO, L. F. Histórico das Ações pró-criação da Divisão Sustentabilidade e Gestão Social e Ambiental. Mensagem recebida por<airtoncardoso@yahoo.com.br> em 21 abr. 2010.

OLIVEIRA, V. A. R. de; CANÇADO, A. C.; PEREIRA, J. R. Gestão social e esfera pública: aproximações teóricoconceituais. Cad. EBAPE.BR [online], v.8, n.4, p. 613-626, 2010. 
PIMENTEL, T. D.; PIMENTEL, M. P. C.; BRITO, M. J. de; PEREIRA, J. R. In FERREIRA, M. A. M.; EMMENDOERFER, M. L; GAVA, R. (Org.). Administração pública, gestão social e economia solidária: avanços e desafios. Viçosa: UFV, 2011, 350p.

PIMENTEL, M. P. C.; PIMENTEL, T. D. Gestão Social: Perspectivas, Princípios e (De)Limitações. In: VI Encontro de Estudos Organizacionais - EnEO, 2010, Florianópolis (SC). Anais... Curitiba (PR): ANPAD, 2010. v. 1. p. 1-16.

PINHO, J. A. G. de. Gestão social: conceituando e discutindo os limites e possibilidades reais na sociedade brasileira. In RIGO, A. S.; SILVA JÚNIOR, J. T.; SCHOMMER, P. C.; CANÇADO, A. C. Gestão Social e Políticas Públicas de Desenvolvimento: Ações, Articulações e Agenda. Recife: UNIVASF, 2010.

POPPER, K. A lógica da pesquisa científica. Tradução de Leônidas Hegenberg e Octanny Silveira da Mota. São Paulo: Cultrix, 2007, 568p.

RAMOS, R. R.; MATOS, I. M.; OLIVEIRA, L. G. L.; COSTA, F. J. da. Importância percebida e intenções de envolvimento com a gestão social: uma análise junto a estudantes de cursos de administração. In Encontro Nacional de Pesquisadores em Gestão Social, 3, 2009, Juazeiro/Petrolina. Anais..., Juazeiro/Petrolina: NIGS/UNIVASF, 2009. 1 CD ROM.

RICO, E. de M.; RAICHELIS, R. (Org.) Gestão social: uma questão em debate. São Paulo: EDUC; IEE, 1999, 231p.

RIGO, A. S.; SIlva JÚNIOR, J. T.; SCHOMMER, P. C.; CANÇADO, A. C. Gestão Social e Políticas Públicas de Desenvolvimento: Ações, Articulações e Agenda. Recife: UNIVASF, 2010.

RIZOTTI, M. L. A.; NISHIMURA, S. R. Gestão social e desenvolvimento territorial: a experiência da cidade de Londrina/PR. In Colóquio Internacional sobre Poder Local, 10, 2006, Salvador. Anais..., Salvador: CIAGS/UFBA, 2006. 1 CD ROM.

ROVIDA, G. A revolução e a guerra na Espanha. In: HOBSBAWN, Eric J. (Org.) História do marxismo VI: o Marxismo na época da Terceira Internacional; A Internacional Comunista de 1919; As Frentes Populares.Rio de Janeiro: Paz e Terra, 1985.

SANTOS, B. de S. Introdução a uma ciência pós-moderna. 4 Ed. Rio de Janeiro: Graal, 2003, 178p.

SASAKI, K.; SOUZA, R. C. de A. Reflexões Sobre a Gestão Social e Ambiental da Comunidade de Artesãos de Porto Sauípe - Bahia. In Colóquio Internacional sobre Poder Local, 10, 2006, Salvador. Anais..., Salvador: CIAGS/UFBA, 2006. 1 CD ROM.

SCHOMMER, P. C.; FRANÇA FILHO, G. C. de. A metodologia da residência social e a aprendizagem em comunidades de prática. In FISCHER, T. M D.; ROESCH, S.; MELO, V. P. Gestão do desenvolvimento territorial e residência social: casos para ensino. Salvador: EDUFBA, CIAGS/UFBA, 63-82, 2006.

.; G_ Gestão social e aprendizagem em comunidades de prática: interações conceituais e possíveis decorrências em processos de formação. In SILVA JR, J. T.; MÂISH, R. T.; CANÇADO, A. C.; SCHOMMER, P. C. Gestão Social: Práticas em debate, teorias em construção. Fortaleza: Imprensa Universitária, 2008.

.; ___ A metodologia da Residência Social e a aprendizagem em comunidade de prática. NAU - Revista Eletrônica da Residência Social do CIAGS/UFBA, Salvador, v.1, n.1, p.203-226 Jun/Nov, 2010.

.; SANTOS, Í. G. dos S. Aprender se aprende aprendendo: construção de saberes na relação entre universidade e sociedade. Salvador: CIAGS/UFBA, FAPESB; SECTI; CNPq, 2010, 162p.

SILVA JR, J. T. Descentrando a pesquisa: o laboratório interdisciplinar de estudos gestão social (LIEGS). In SILVA JR, J. T.; MÂISH, R. T.; CANÇADO, A. C.; SCHOMMER, P. C. Gestão Social: Práticas em debate, teorias em construção. Fortaleza: Imprensa Universitária, 2008a. 
. O futuro da gestão social. In SILVA JR, J. T.; MÂISH, R. T.; CANÇADO, A. C.; SCHOMMER, P. C. Gestão Social: Práticas em debate, teorias em construção. Fortaleza: Imprensa Universitária, 2008 b.

.; MÂISH, R. T.; CANÇADO, A. C. Gestão Social: Práticas em debate, teorias em construção. Fortaleza: Imprensa Universitária, 2008a.

.; ___ ___ _ _ _ _ SCHOMMER, P. C. Introdução. In: SILVA JR, J. T.; MÂISH, R. T.; CANÇADO, A. C.; SCHOMMER, P. C. Gestão Social: Práticas em debate, teorias em construção. Fortaleza: Imprensa Universitária, 2008c.

.; ___ ; RAMOS, R. R.; MEDEIROS, A. C.; VIANA, T. de A. Articulando diferentes metodologias de aprendizagem no ensino de gestão social na graduação: uma proposta do Curso de Administração da UFC-Campus Cariri. In CANÇADO, A. C.; SILVA JR, J. T.; SCHOMMER, P. C., RIGO, A. S. Os desafios da formação em gestão social. Palmas-TO: Provisão, 2008 b.

SINGER, P. Alternativas da gestão social diante da crise do trabalho. In RICO, E. de M.; RAICHELIS, R. (Org.) Gestão social: uma questão em debate. São Paulo: EDUC; IEE, 1999, 231p.

SUBIRATS, J. Cidadania e espaço público: a perspectiva da gestão social. (posfácio) In TENÓRIO, F. G. (Org). Cidadania e desenvolvimento local. Rio de Janeiro: FGV; Ijuí: UNIJUÍ, 2007, 632p.

TENÓRIO, F. G. A trajetória do Programa de Estudos em Gestão Social (Pegs). Rev. Adm. Pública, v.40, n.6, dez., 2006.

(Org.). Gestão social: metodologia e casos. 5 ed. Rio de Janeiro: Editora FGV, 2007a.

. (Org). Cidadania e desenvolvimento local. Rio de Janeiro: FGV; Ijuí: UNIJUÍ, 2007b, 632p.

Tem razão a administração? 3 Ed. Ijuí: Editora da Unijuí, 2008a.

Um espectro ronda o terceiro setor, o espectro do mercado. 3 Ed. Ijuí: Editora da Unijuí, 2008 b.

. A trajetória do programa de estudos em gestão social (PEGS). In SILVA JR, J. T.; MÂISH, R. T.; CANÇADO, A. C.; SCHOMMER, P. C. Gestão Social: Práticas em debate, teorias em construção. Fortaleza: Imprensa Universitária, 2008c.

Gestão Social: uma réplica. In RIGO, A. S.; SILVA JÚNIOR, J. T.; SCHOMMER, P. C.; CANÇADO, A. C. Gestão Social e Políticas Públicas de Desenvolvimento: Ações, Articulações e Agenda. Recife: UNIVASF, 2010.

Gestão social, um conceito não-idêntico? Ou a insuficiência inevitável do pensamento, 2011 ( no prelo).

.; SARAIVA, H. J. Escorços sobre gestão pública e gestão social. In MARTINS, P. E. M.; PIERANTI, O. P. Estado e gestão pública: visões do Brasil contemporâneo. 2 Ed. Rio de Janeiro: FGV, 2006, 340p.

WANDERLEY, L. S. O.; LIMA, S. M. da S.; PASA, C. Liberdades instrumentais do Amartya Sen na gestão social de territórios. In Colóquio Internacional sobre Poder Local, 10, 2006, Salvador. Anais..., Salvador: CIAGS/UFBA, 2006.1 CD ROM. 